\title{
CULTURA E IDENTIDADE NO CONTEXTO DA DIÁSPORA: UMA CONSTRUÇÃO HISTÓRICA
}

\section{CULTURE AND IDENTITY IN THE CONTEXTO OF DIASPORA: A HISTORICAL CONSTRUCTION}

Iorim Rodrigues da Silva ${ }^{1}$

Rosalva P. de Alencar ${ }^{2}$

HALL, Stuart. Da Diáspora: Identidades e Mediações Culturais. Org. Liv Sovik; Tradução Adelaine La Guardia Resende...[et al.] Belo Horizonte: Editora UFMG; Brasília; Representação da UNESCO no Brasil, 2003.

O livroDa Diáspora: Identidades e Mediações Culturais tem suas origens na vinda de Hall ao Brasil em julho de 2000 quando proferiu uma palestra na Bahia, na sessão de abertura do VIII Congresso da Associação Brasileira de Literatura Comparada. Nele Hall nos convida a participar não de um diálogo sobre cultura e identidade cultural, mas de um diálogo entre correntes de pensamento distintas e divergentes sobre a construção da identidade cultural nas relações sociais. Apresenta a temática como algo que não é fixo, mas como resultado de formações históricas e híbridas, de histórias e repertórios culturais que se pode chamar de identidade.

É interessante observar o modo como Hall (2003), traz a concepção de identidade cultural na perspectiva dispórica,

[...] a identidade é irrevogavelmente uma questão histórica. Nossas sociedades são compostas não de um, mas de muitos povos. Suas origens não são únicas, mas diversas. Aqueles aos quais originalmente a terra pertencia, em geral, pereceram há muito tempo - dizimados pelo trabalho pesado e a doença. A terra não pode ser "sagrada" pois foi "violada" - não vazia, mas esvaziada. Todos que estão aqui pertenciam originalmente a outro lugar. Longe de constituir uma continuidade com os nossos passados, nossa relação com essa história está marcada pelas rupturas mais aterradoras, violentas e abruptas. (HALL, 2003, p.30).

\footnotetext{
${ }^{1}$ Doutorando do Programa de Pós Graduação em Educação da Universidade Federal de Mato Grosso, campus Cuiabá, professor da Escola Municipal Rural Carimã, em Rondonópolis/MT, e-mail: i-orin@hotmail.com ${ }^{2}$ Doutoranda do Programa de Pós Graduação em Educação da Universidade Federal de Mato Grosso, campus Cuiabá, professora da Universidade do Estado de Mato Grosso, lotada na Faculdade de Educação e Linguagem, campus Jane Vanini, em Cáceres/MT, e-mail: rosalvalencar@gmail.com
} 
Portanto, para Hall, a Cultura é determinante na constituição da identidade, conforme o autor relata:

Fui sempre identificado em minha família como alguém de fora, aquele que não se adequava, o que era mais negro que os outros (...) passei minha adolescência negociando espaços culturais (...) vivi as tensões coloniais clássicas como parte da minha historia pessoal. Minha própria formação e identidade foram construídas a partir de uma espécie de recusa dos modelos dominantes de construção pessoal e cultural aos quais fui exposto. Aprendi, em primeiro lugar, que a cultura era algo profundamente subjetivo e pessoal, e ao mesmo tempo, uma estrutura em que a gente vive. (HALL, 2003, p. 408)

Ele relata que quando ele tinha uns dezessete anos, sua irmã teve um colapso nervoso. Tudo porque ela começou um relacionamento com um estudante de medicina. Ele era de classe media, mas era negro e seus pais não permitiram o namoro. Houve uma tremenda briga em família e ela, na verdade, recuou da situação e entrou em crise. Esse fato foi preponderante para a sua conscientização da contradição da cultura colonial, de como se sobrevive à experiência da dependência colonial, de classe e cor e de como isso pode ser destrutivo, subjetivamente.

A identidade cultural na diáspora não pode ser pensada como se fosse "fixada no nascimento, parte integrante da natureza humana, impressa através do parentesco e da linhagem dos genes: a identidade é irrevogavelmente uma questão histórica". (HALL, 2003, p.28). Deslocamento, aliás, é a centralidade que Hall faz da relação da cultura com estruturas sociais de poder. A riqueza das discussões presentes no livro, também, pode ser encontrada na busca de conceitos como Cultura, Multicultural, Multiculturalismo, Globalização, a presença do Hibridismo na formação cultural; além do seu olhar sobre o lugar da historia no estudo da cultura contemporânea, e a maneira pela qual lê questões das etnicidades dominantes e de gênero.

Ler Hall é perceber que ele aborda a constituição das identidades caribenhas sob as condições contemporâneas de globalização. Eles têm suas raízes nos quatro cantos do globo, desde a Europa, África, Ásia. "Suas 'rotas' são tudo, menos 'puras', sua cultura é o resultado entrelaçamento e fusão de diferentes elementos culturais africanos, asiáticos e europeus". (HALL, 2003, p.31). Pensa a África como elemento que sobreviveu e como meio de sobrevivência na diáspora. Defende a hibridização ou "impureza" cultural como 
uma forma em que o "novo entra no mundo". Para ele, essa "impureza" é em si uma condição a sua modernidade. Isso não quer dizer que numa formação sincrética, os elementos diferentes estabelecem uma relação de igualdade uns com os outros.

Essa ideia nos remete aos conceitos de "Multicultural" e "Multiculturalismo". Para Hall, esses termos são atualmente universalizados, no entanto, a sua proliferação não contribuiu para estabilizar ou esclarecer seus significados,

\begin{abstract}
'Multicultural' é um termo qualificativo. Descreve as características sociais e os problemas de governabilidade apresentados por qualquer sociedade na qual diferentes comunidades culturais convivem e tentam construir uma vida em comum, ao mesmo tempo em que retêm algo de sua 'identidade original... . "Multiculturalismo" é substantivo, refere-se às estratégias e políticas adotadas para governar ou administrar problemas e multiplicidade gerados pelas sociedades múltiplas. (HALL, 2003, p. 52).
\end{abstract}

Desta maneira, é possível compreendermos que cada identidade é própria e se constitui na hibridização, no movimento de articulação: será sempre provisória tendo em vista os vários encontros que causam choque e entrechoques das culturas. Traz à tona as fragilidades e limitações das sociedades diante do colonialismo e as consequências no pós-colonialismo. Esse sistema marcou para sempre as sociedades dominadas, a diversidade era pretexto para a imposição de valores, de costumes culturais.

Hoje, os processos das chamadas migrações livres e forçadas estão mudando de composição, diversificando as culturas e pluralizando as identidades culturais do próprio globo. Os fluxos não regulados de povos e culturas são tão amplos e tão irrefreáveis quanto os fluxos patrocinados do capital e da tecnologia, como cultura homogeneizante: "McDonald-ização" ou "Nikezação" de tudo (HALL, 2003, p.45).

As discussões propostas por Hall (2003) dialogam com a ideia da presença do fator econômico nessas relações. O engajamento de Hall com Marx se dá pelo fato dele se sentir atraído por uma teoria do capital e classe social, de poder e exploração, da prática da produção de conhecimentos críticos; mas discordava de Marx pelo espaço relativamente pequeno destinado à cultura em suas discussões.

Mas é com Gramsci que ele se identifica, pelas possibilidades de avanços em algumas temáticas, ignoradas ou esquecidas por outros autores. Filia-se ao método e às prioridades de Gramsci, dentre as quais está a fazer um 
trabalho teórico que contribua para uma ideologia e uma cultura "populares", em contraposição à cultura do bloco de poder, ao mesmo tempo em que se desconfia do alcance político limitado do trabalho intelectual.

Gramsci não escreveu sobre raça, etnia ou racismo, nem analisou em profundidade a experiência colonial ou o imperialismo, de onde se desenvolveram tantas das características e relacionamentos "racistas" do mundo moderno. Ainda que não o tenha feito, seus conceitos podem ser úteis a nossa tentativa de pensar a suficiência dos paradigmas da teoria social nessas áreas. Não se trata de "uma simples transferência das ideias de Gramsci para essas questões" (HALL, 2003, p. 326), "mas de uma reflexão sobre as temáticas abordadas por ele e que podem ser úteis nessa direção". (HALL, 2003, p.333)

Ao abordar a questão da Cultura Popular Negra, traz para o diálogo autores como West, Arnold e Franz Fanon, enfatizando que o momento da questão da cultura negra está divida em três grandes eixos:

O primeiro é o deslocamento dos modelos europeus de alta cultura, e da própria cultura [...]; o segundo eixo é o surgimento dos EUA, como potência mundial e, consequentemente, como centro de produção e circulação global da cultura [...]; o terceiro eixo é a descolonização do Terceiro Mundo no sentido de Franz Fanon: incluo aí o impacto dos direitos civis e as lutas negras pela descolonização das mentes dos povos da diáspora negra. (HALL, 2003, p. 336)

Hall atenta-se para o fato de que a questão da Cultura Popular Negra está inserida em no contexto da ideologia americana e que os negros estão colocados numa relação tão ambígua com o pós-modernismo quanto estavam com o alto modernismo; e que esses dois períodos não conseguiram dar conta da realidade da questão da cultura popular negra como um todo.

Para Hall (2003), a cultura popular carrega uma ressonância afirmativa por causa do peso da palavra "popular" que é o de fixar a autenticidade das formas populares, enraizando-as nas experiências das comunidades populares. Ela chegou a significar a comunidade negra onde se guardam as tradições e costumes cujas lutas sobrevivem na persistência da experiência negra (a experiência histórica do povo negro na diáspora), da estética negra (os repertórios culturais próprios a partir dos quais foram produzidas as representações populares) e das contra narrativas negras que lutamos para expressar.

O último capítulo é uma entrevista com o próprio autor conduzida por Kuan-Hsing Chen. Nessa entrevista são abordadas questões relativas à raça, 
à etnia, às especificidades de várias trajetórias que moldaram a experiência, posição política e intelectualidade do autor.

Data de recebimento: 03.03.2018

Data de aceite: 28.03 .2018 